\title{
An Indonesian Democracy: Limits of a Majoritarian Democracy
}

\author{
Ben Kristian Citto Laksana \\ Jurusan Ilmu Hubungan Internasional, International University Liaison Indonesia \\ E-mail: ben.laksana@iuli.ac.id.
}

\begin{abstract}
Indonesia has continuously been praised as a successful post-authoritarian country transitioning to democracy. However, seeing the numerous human rights violations in the past decade alone especially towards alternative political, religious and sexual identities, the success of democracy in Indonesia has been put under the spotlight. This raises the question of the development of democracy and the use of democracy in Indonesia in practicing and upholding principles of social equality for all. In this article I wish to provide an overview of majoritarian democracy, a form of democracy that is understood and practiced in Indonesia. A form of democracy that rather than upholding values that safeguards individual rights and diversity, may in fact undermine religious and cultural diversity, enforcing a homogenized national culture and values, which in return may engender human rights violations in the name of national security that it in itself is defined by the majority.
\end{abstract}

Keywords: indonesian democracy, majoritarian democracy, musyawarah mufakat

\begin{abstract}
Abstrak
Indonesia telah seringkali dipuji sebagai negara pasca-otoriter yang sukses bertransisi ke demokrasi. Namun, melihat banyaknya pelanggaran hak azasi manusia selama satu dekade lalu ini saja, terutama terhadap identitas politik, agama dan seksual yang alternatif, keberhasilan demokrasi di Indonesia saat ini patut berada di bawah sorotan. Hal ini menimbulkan pertanyaan tentang perkembangan dan implementasi demokrasi di Indonesia dalam menjalankan dan menegakkan prinsip-prinsip kesetaraan sosial untuk seluruh rakyatnya. Dalam artikel ini, saya ingin memberikan gambaran mengenai majoritarian democracy, bentuk demokrasi yang dipahami dan dipraktikkan di Indonesia. Sebuah bentuk demokrasi yang tidak menjunjung tinggi nilai-nilai yang melindungi hak-hak individu dan keberagaman bahkan memungkinkan untuk merusak keberagaman agama dan budaya, dan memaksakan homogenitas budaya dan nilai-nilai nasional yang pada akhirnya dapat melahirkan pelanggaran hak azasi atas nama keamanan nasional yang didefinisikan oleh kaum mayoritas itu sendiri.
\end{abstract}

Kata-kata kunci: demokrasi indonesia, demokrasi majoritarian, musyawarah mufakat

\section{Introduction}

The globalization of political process has increasingly resulted in the homogenization of how politics is performed namely through successive 'waves' of democratic transition. However, the mass dissemination of democracy is not necessarily accompanied by a deeper deliberative effort in questioning the potential of demrocracy as a possible detrimental political system towards inclusivity and human rights. Namely within post-authoritarian societies where the development of democracy has been limited to majoritarian democracy. A form of government, where Conversi argues, "which decisions are taken according to the principle of majority rule, is identified as the institutional context where the populistpatriotic drift can degenerate, pulverizing itself 
into self-destruction." ${ }^{\prime 1}$ In defense of this absence of a qualitative inquiry into democracy, the stale label of 'transition to democracy' is often employed as a necessary justification for the global promotion of democracy. Even if the promoted version of democracy is visibly limited to majoritarian values, especially in former authoritarian countries, such as Indonesia.

Indonesia having recovered from the 1997-1998 Asian financial crisis which resulted in the tumultuous 1998 reformation and marking an end to Soeharto's authoritarian rule, has often been praised by the international community for purportedly being a model for a Muslim democracy. Although Indonesia in itself is not an Islamic state, it is a Muslim majority country under democracy, thus the compatibility of Islam and democracy is often stressed by state officials. Such as Indonesia's current President Joko Widodo, where during his overseas trips has constantly promoted Indonesia's Muslim democracy. This is nothing short of new as harmony of Indonesia's Muslim democracy has also been touted during Susilo Bambang Yudhoyono's ten-year presidency prior to Jokowi Widodo. ${ }^{2}$

While it has been evident that Indonesia has made great strides in securing a stable Muslim majority democratic government after decades of authoritarian rule, the country is by no

\footnotetext{
${ }^{1}$ Daniele Conversi, "Majoritarian Democracy and Globalization Versus Ethnic Diversity?," Democratization 19, no. 4 (2011).

2 Andreas Harsono, "No Model for Muslim Democracy," The New York Times 2012.
}

means a stronghold of democratic values that sustain diversity, be it religious, cultural or political. Early 2016 saw the rise of an unanticipated resurgence of mass anticommunist movements as a reaction of authorities discovering $\mathrm{t}$-shirts, stickers and paraphernalia engraved of the familiar communist hammer and sickle symbol, representing an ideology that has been banned since the late $60 \mathrm{~s} .{ }^{34}$ Shortly following that and an ever continual contentious topic up to this day, the dramatic and punitive response of many officials and ordinary citizens in trying to curb homosexuals in Indonesia have shown the constant struggle a number of Indonesians face in attempting to embrace their sexual identities. ${ }^{56}$ It must be mentioned however that these rejections of certain political and sexual identities sweep across religion and is not only restricted to Islam.

These socio-political tension is in addition to the already straining religious friction becoming more apparent, not only inter-religious but intra-religious as well. A common example would be the closing and

\footnotetext{
${ }^{3}$ Tempo, "Polisi Sukabumi Tangkap Pengusaha Kaus Palu Arit," Tempo, https://m.tempo.co/read/news/2016/05/31/0587754 19/polisi-sukabumi-tangkap-pengusaha-kaus-paluarit.

${ }^{4}$ Jakarta Globe, "Communist Symbolism, Debates Spring up on Social Media and Streets," Jakarta Globe, http://jakartaglobe.beritasatu.com/news/hold-fordonny-the-rise-of-communism-in-indonesia/. ${ }^{5}$ HumanRightsWatch, "Indonesia: 'Lgbt Crisis' Exposed Official Bias," HumanRightsWatch, https://www.hrw.org/news/2016/08/10/indonesialgbt-crisis-exposed-official-bias.

${ }^{6}$ Newsweek, "Indonesia: There Is 'No Room' for the Lgbt Community," Newsweek, http://www.newsweek.com/indonesia-says-thereno-room-lgbt-community-489314.
} 
burning of a number of churches across Indonesia as well as the persecution of minority Muslim sects, the Shia Muslims and the Ahmadis, by the majority Sunni Muslims. Which culminated in the banning and prosecution of these minorities by the state and society. These brief examples not only provide a general overview of the growing conservatism and intolerance within Indonesia's society, but also provide an impression of how many societal and state actions have been legitimized by the majority. The potential result of this, as Cederman et. al. further considers, are how countries in transitions to democracy, such as Indonesia, opens up formerly strict political spaces yet due to weak political institutions and the exploitation of populist ideals, the 'elite competition' is ineffectively regulated and "may cause civil war".

In examining these diversity issues it is tempting to understand it through Samuel Huntington's rationale, in which he argues that as many cultures contradict with the values of democracy not all societies are likely to develop fully democratic institutions. ${ }^{8}$ Yet to look through such a narrow perspective would be to sacralize democracy and solely condemn everything external of democracy. We must also question how democracy itself is understood within a former repressive country and how, with values inconsistent with

\footnotetext{
${ }^{7}$ Lars-Erik Cederman, Simon Hug, and Andreas Wenger, "Democratization and War in Political Science," Democratization 15, no. 3 (2008); ibid.

${ }^{8}$ Samuel Huntington, "The Clash of Civlizations?," Foreign Affairs 72, no. 3 (1993).
}

democracy, has contributed in the development of a semi-authoritarian (anocratic) country that boasts itself of being a democracy but simultaneously rigorously limits society.

In this article I wish to provide an overview of how we might think of the form of democracy that is understood and practiced in Indonesia namely majoritarian democracy. A form of democracy that may undermine religious and cultural diversity, enforcing a homogenized national culture and values, which in return may engender human rights violations in the name of national security that it in itself is defined by the majority. ${ }^{9}$ This emphasis on national security, as Ashis Nandy notes, can not only become disjoined with people's individual security but may even prompt an opposing relationship with people's security. ${ }^{10}$ Additionally, although the international community has constantly praised Indonesia as a prime example of Islam and democracy living side by side peacefully yet the unfavorable and unintended outcomes of a majoritarian democracy particularly towards the marginalized communities coupled with the unacknowledged growth of values limiting diversity may only have further aggravated socio-political and religious tensions within Indonesia's society.

\section{Globalizing democracy}

\footnotetext{
${ }^{9}$ Conversi.

10 Ashis Nandy, "Culture, State, and the Rediscovery of Indian Politics," in Literary India: Comparative Studies in Aesthetics, Colonialism and Culture, ed. Patrick Colm Hogan and Lalita Pandit (Albany, NY: State University of New York Press, 1995).
} 
In analyzing the globalization of democracy Kathleen Schwartzmann asks "how can global change constitute a catalyst for the transition-to-democracy?"11 Through this question the underlining idea here is to understand the connection of global events with domestic ones, and see how that in itself has effected both the leaders and societies of a particular nation-state. Employing this idea of interconnectedness, Indonesia is a central example of how global processes can influence the domestic political process. Although the shift to democracy in Indonesia was hailed as a major development of Indonesia's civil movement, the movement itself was also simultaneously driven by a regional event, the 1997 Asian monetary crisis.

Democracy is an ideal political process to undertake as the result of economic globalization and integration, namely a globalization of production or in Indonesia's case an economic crisis, as it has led to new forms of class conflict and led to new social movements, which authoritarian states found tough to restrain. Here Schwartzmann argues that democratization is the most fitting response of the state's struggle to restrain its people as it can actually reduce people's levels of mobilization and participation. ${ }^{12}$ It is through democracy that developing countries are more peacefully aided through the contentious and abrasive process of global integration by transforming the impassioned

11 Kathleen C. Schwartzman, "Globalization and Democracy," Annual Review of Sociology 24 (1998).

${ }^{12}$ Ibid. working class into democratic citizens. As democracy in itself encourages citizens to participate "on the basis of unlimited collective identities", i.e. having them proceed to embrace their personal ethno-religious-political identities, it enhances individualization and breaks down inter-class relations that they initially began with. ${ }^{13}$ The shared mass collective identity that is constructed through a shared suffering prior to a democracy is, paradoxically, deconstructed into smaller identities partly owing to the introduction of democracy and its more open, diversity fostering, values.

Additionally, the effort of globalizing democracy as the prime political process is often underpinned through a prevailing dogma in political science that "democracies rarely fight one another because they share common norms of live-and-let-live and domestic institutions that constrain the recourse to war", the democratic peace theory. ${ }^{14}$ Proponents of the democratic peace theory contends that liberal democracy promotes not only harmony between nations, but as peace is achieved between democracies, peace will also be attained within democracies. However, the theory that democracies rarely engage in violence have proven false, most strikingly when using the false pretense of 'normalizing emergency powers'. Due in part to the assumption that emergency situations are uncommon, exceptional and short-term, the notion of emergency ethics becomes

\footnotetext{
13 Ibid.

${ }^{14}$ Conversi.
} 
compelling to accept, "yet in reality temporary emergency measures tend to become part of the normal functioning of the state". ${ }^{15}$

Indonesia sets an example of this, as the reoccurrence of moral panics, for instance the recent 'LGBT scare' where LGBTs are seen as a sign of moral decay, are often used to induce various forms of public emergencies, often morally motivated and ending in the persecution and prosecution of the 'other'. Something of a growing occurrence within Indonesia's socio-political environment. Furthermore recent developments of Indonesia's nationalism in which Aspinall argues, "contemporary nationalism's markedly non-ideological and non-intellectual form; continuity is visible in its discursive style, with many contemporary nationalists anachronistically reproducing tropes rooted in earlier period,“ (emphasis added) have equally contributed in the impression that Indonesia is undergoing forms of emergency situations, namely due to 'foreign hostilities'. ${ }^{16}$ A reiterated, ill specified common enemy used by elites to provoke an atmosphere of urgency. A recent clear example of this, as Aspinall observed, President Jokowi has urged young entrepreneurs to engage more actively in the domestic market 'so to prevent 'foreign businesspeople' from 'menduduki' (meaning 'occupying' - a word associated with armed conquest) the Indonesian market. ${ }^{17}$ Taking

\footnotetext{
${ }^{15}$ Ibid.

16 Edward Aspinall, "The New Nationalism in Indonesia," Asia \& the Pacific Policy Studies Special Issue (2015).

${ }^{17}$ Ibid.
}

these events into note, not only do democracies engage in forms of violence but through public emergencies has done so with the garnered support of the majority.

Indonesia, if only witnessed through the simplest manifestation of democracy which stresses nothing more than free elections, an electoralist fallacy, and the voices of the majority as a sufficient condition for democracy is well indeed a democracy but a deeply restricted one at best. "Free elections and voting cannot provide a political panacea, as manipulative elites are ready to cynically externalize internal tensions through diversionary war and destructive developmental projects". $^{18}$ Through democracy, nation-states have been able to legitimize social-violence and even state violence. Democracy then has become a mere reason to oppress, such as what has been lamented by Appadurai, "one man's imagined community, is another man's political prison". ${ }^{19}$ Rather than globalizing limited democracies that stresses nothing more than free elections and voting, the export of democracy, aside from a free press, should center on instruments that can magnify the rule of law and good administration, matters that are often flailing in countries transitioning to democracy. ${ }^{20}$ This then naturally raises the question of the forms of democracy itself as not all democracies are equal in stature and

\footnotetext{
${ }^{18}$ Conversi.

${ }^{19}$ Arjun Appadurai, "Disjuncture and Difference in the Global Cultural Economy," Theory Culture Society 7 (1990).

${ }^{20}$ Schwartzman.
} 
constitution, specifically how should democracy in Indonesia be defined?

This question however depends on the method of measuring democracy itself as debates regarding how a democracy should be measured has not been resolved. Scholars have debated on whether democracy should focus on the democratic institutions available (or not) in which the mass participation of individuals in a decision making process are fostered but with limited choices conducted in periodic elections; a limited democracy or polyarchy, or should democracy not only center on the mass participation of majorities in decision making but also be defined through the degree of liberty an individual has in achieving social and economic justice. ${ }^{2122}$ Furthermore, as diversity is a condition of which Indonesia takes great interest in, it must also be mentioned that while some forms of democracy sustain diversity others undermine many forms of diversity.

To understand a democracy that embraces diversity we must first understand the notion multiculturalism as an underlying stance in embodying diversity. "Multiculturalism is the political and social practice based on the recognition, respect and promotion of cultural difference."23 Cultural homogenization is the opposite of

21 Kenneth A. Bollen and Robert W. Jackman, "Democracy, Stability, Dichotomies," American Sociological Review 1989, no. 54 (1989).

22 William I. Robinson, Promoting Polyarchy: Globalization, Us Intervention, and Hegemony (UK: Cambridge University Press, 1996).

${ }^{23}$ Conversi. multiculturalism in which all of the of the above are denied which Conversi understands this as the result of deliberate actions in centralizing power by the state. ${ }^{24} \mathrm{He}$ further argues that although it seems that a denial of diversity simply inflicts those who are deprived of their rights, the effect extends to the whole of society. It not only limits, denies and weakens human relationships within the society but also diminishes collective social resistance and promotes the synthesizing of power elites.

The attempt of cultural homogenization itself has historically been associated with states founded on warfare. ${ }^{25}$ As the very conception of such a modern nationstate is to construct and preserve a dominant national culture that can be used as a unifying factor in establishing a common goal of defeating a common enemy. Looking back at Indonesia's struggle for independence, in the effort defending itself of the Dutch and Japanese colonizers, constructing a national culture was an essential pragmatic requirement. Despite this, the development of having a national culture that is then ill-defined into strict cultural homogenization, becomes an essential requirement for a democracy that extends only to the interests of the majority. ${ }^{26}$

\section{Indonesia's Democracy of 'Musyawarah and Mufakat'}

If democracy in itself is multi-
${ }^{24}$ Ibid.

25 Ibid.

${ }^{26}$ Ibid. 
interpretative and as previously discussed can either be a misfortune to diversity or if defined correctly can be a boon, how does Indonesia then promote and maintain its limiting democracy especially through a national culture? In 'Illiberal Democracy in Indonesia' David Bouchier discusses the emphasis of the Indonesian term 'musyawarah and mufakat', which roughly translates into 'discussions with the many to achieve collective agreements' in having officials and eventually everyday citizens define democracy as the strict will of the majority.

This emphasis is mostly visible in Indonesia's Citizenship Education where recently in 2013 the Yudhoyono government began introducing a new curriculum, that gave prominence to development of an individual's religious and moral education with expense of science, social studies and English. Bouchier observed that in the 2013 curriculum, Citizenship Education was not only changed back to Soeharto's New Order era name, Pancasila and Citizenship Education but the prominence of subjects on human rights, power, politics and globalization were greatly reduced if not removed. ${ }^{27}$ "Democracy in the new curriculum was still regarded as a positive value but only when tempered by Indonesian cultural norms and national imperatives". ${ }^{28}$ Great importance was given to the 'four pillars of nationhood' namely: (1) Pancasila as the basis of the state and the worldview of the

27 David Bouchier, Illiberal Democracy in Indonesia: The Ideology of the Family State (New York: Routledge, 2015).

${ }^{28}$ Ibid. nation; (2) the 1945 Constitution; (3) Unity in Diversity; (4) the Unitary State of the Republic of Indonesia (NKRI). ${ }^{29}$

Here the usage of musyawarah and mufakat is reiterated and prioritized as one of the core aims of the curriculum. Such for instance the senior high school curriculum, was aimed to "encourage a culture of democracy that prioritizes musyawarah and mufakat and national integrity in the context of NKRI". ${ }^{30}$ What this information provides is how the government intends to define the development of democracy in Indonesia, namely by limiting democracy through a definition of Indonesia's culture that does not center on individual rights but communal interests.

This idea of a democracy that puts weight in communal interests has also been mirrored by government officials, politicians, political parties and a sizable part of Indonesia's society. A clear example of this can be seen in the recent 2014 presidential election. The leader of the Gerindra party, Prabowo Subianto, presented Gerindra as a guardian of an authentic Indonesian nationalism, that in itself was anchored in the past. $^{31}$ Not only did Prabowo draw on

29 Balitbang-Puskurbuk-Kemdikbud, "Centre for Curriculum and Textbooks Research and Development Body," Ministry of Education and Culture, http://puskurbuk.net/web13.

30 Kemdikbud, "Kurikulum 2013, Kompetensi Dasar, Sekolah Menengah Atas Madrasah Aliyah," ed. Kementerian Pendidikan dan Kebudayaan (Jakarta: Kementerian Pendidikan dan Kebudayaan RI, 2013).

${ }^{31}$ Bouchier. 
Soekarno's anti-imperialist rhetoric but also sought, through his election campaign advertisements, that the only way to resolve poverty and political instability "was to abandon liberal political and economic policies and return to a political system based on strong centralized leadership and indigenous Indonesian values." ${ }^{32}$ Furthermore Gerindra stressed thoroughly on the principles of gotong royong (working together) and musyawarah as seen in its manifesto, which they described as a "unique expressions of Indonesian culture" that "prioritize the interests of the group over that of the individual." ${ }^{, 33}$ As Gerindra believes it is faced with a choice, "the prosperity of the people" or the "unbounded freedoms of democracy", with such a choice to make "Gerindra opts for the prosperity of the people in accordance with the preamble of the 1945 Constitution". By choosing so Gerindra has defined the method of pursuing people's prosperity through the heavy-hand of authoritarianism that is validated by the majority of the people themselves. In the recent general elections of 2014 Gerindra managed to become Indonesia's third largest party and in the presidential election of the same year, Prabowo Subianto won 46.8 percent of the vote. This evidence of how Gerindra's views on conservative nationalism and Indonesia's excessively liberal democracy

\footnotetext{
${ }^{32}$ Dirk Tomsa, Party Politics and Democratization in Indonesia: Golkar in the Post-Suharto Era (London: Routledge, 2008).

33 Partai Gerindra, "Manifesto Perjuangan Partai Gerakan Indonesia Raya," Partai Gerindra, http://partaigerindra.or.id/manifesto-perjuanganpartai-gerindra.
}

that is seemingly disconnected with not only the constitution but also Indonesia's culture of musyawarah and mufakat, has steadily become a part of Indonesian's mainstream sociopolitical ideals.

\section{Conclusion: Indonesia's limited democracy}

Indonesia has constantly been praised as a nation-state that is not only successful in transitioning to a democracy from an authoritarian regime, but also as democracy that can thrive with a Muslim majority. However as numerous incidents following reformasi have shown Indonesia has continuously undermined individual rights, especially those regarding to alternative sexual, political and religious identities. These practices of the state though is not merely a self-centered authoritarian attempt but rather it is sanctioned by a substantial number of Indonesians through cultural values such as musyawarah and mufakat producing a majoritarian form of democracy. It is through this type of democracy that majoritarian democracy becomes the overarching condition in the recurrence of mass crimes against humanity and diversity. With minorities having few possibilities of voicing their concerns and methods of escape, it is possible to agree that majoritarian democracies contain the seeds of extreme ethnic discrimination, which in return may lead to "cumulative measures aimed at diversity elimination spiraling out of control." ${ }^{34}$

Seeing how Indonesia manages

\footnotetext{
${ }^{34}$ Conversi.
} 
diversity in its society, in measuring democracy and hence defining it, Indonesia clearly struggles in achieving social and economic justice that transcend diversity issues especially when seen through the degree of liberty an individual has. Whether it be sexual, political or religious orientation, Indonesia has constantly made deliberate effort to limit unconventional notions of identities. The ideal here rests on the ideals of the community rather than the rights of the individual. To define Indonesia as democratic state that is also able to indulge itself in religion would only be partially true. However, what is alarming is not only the current state that it is in but the path that its current form of 'majority defined democratic political process' is on.

\section{Bibliography}

Appadurai, Arjun. "Disjuncture and Difference in the Global Cultural Economy." Theory Culture Society 7 (1990): 295310.

Aspinall, Edward. "The New Nationalism in Indonesia." Asia \& the Pacific Policy Studies Special Issue (2015).

Balitbang-Puskurbuk-Kemdikbud. "Centre for Curriculum and Textbooks Research and Development Body." Ministry of Education and Culture, http://puskurbuk.net/web13.

Bollen, Kenneth A., and Robert W. Jackman. "Democracy, Stability, Dichotomies." American Sociological Review 1989, no. 54 (1989): 612-21.

Bouchier, David. Illiberal Democracy in Indonesia: The Ideology of the Family State. New York: Routledge, 2015.

Cederman, Lars-Erik, Simon Hug, and Andreas Wenger. "Democratization and War in Political Science." Democratization 15, no. 3 (2008): 50924.

Conversi, Daniele. "Majoritarian Democracy and Globalization Versus Ethnic Diversity?". Democratization 19, no. 4 (2011): 789-811.

Gerindra, Partai. "Manifesto Perjuangan Partai Gerakan Indonesia Raya." Partai Gerindra, http://partaigerindra.or.id/manifestoperjuangan-partai-gerindra.

Globe, Jakarta. "Communist Symbolism, Debates Spring up on Social Media and Streets." Jakarta Globe, http://jakartaglobe.beritasatu.com/new s/hold-for-donny-the-rise-ofcommunism-in-indonesia/.

Harsono, Andreas. "No Model for Muslim Democracy." The New York Times, 2012.

HumanRightsWatch. "Indonesia: 'Lgbt Crisis' Exposed Official Bias." HumanRightsWatch, https://www.hrw.org/news/2016/08/10 /indonesia-lgbt-crisis-exposed-officialbias.

Huntington, Samuel. "The Clash of Civlizations?". Foreign Affairs 72, no. 3 (1993): 14-33.

Kemdikbud. "Kurikulum 2013, Kompetensi Dasar, Sekolah Menengah Atas Madrasah Aliyah." edited by Kementerian Pendidikan dan Kebudayaan. Jakarta: Kementerian Pendidikan dan Kebudayaan RI, 2013.

Nandy, Ashis. "Culture, State, and the Rediscovery of Indian Politics." In Literary India: Comparative Studies in Aesthetics, Colonialism and Culture, edited by Patrick Colm Hogan and Lalita Pandit. Albany, NY: State University of New York Press, 1995.

Newsweek. "Indonesia: There Is 'No Room' for the Lgbt Community." Newsweek, http://www.newsweek.com/indonesiasays-there-no-room-lgbt-community489314. 
Robinson, William I. Promoting Polyarchy: Globalization, Us Intervention, and Hegemony. UK: Cambridge University Press, 1996.

Schwartzman, Kathleen C. "Globalization and Democracy." Annual Review of Sociology 24 (1998): 159-81.

Tempo. "Polisi Sukabumi Tangkap Pengusaha Kaus Palu Arit." Tempo, https://m.tempo.co/read/news/2016/05/ 31/058775419/polisi-sukabumitangkap-pengusaha-kaus-palu-arit.

Tomsa, Dirk. Party Politics and Democratization in Indonesia: Golkar in the Post-Suharto Era. London: Routledge, 2008. 